\title{
Sistem Pemantau Posisi Wireless Access Point Menggunakan Antena Directional
}

\author{
Desy Apriani ${ }^{1}$, Dewi Immaniar ${ }^{2}$, Muhammad Zainal Arifin ${ }^{3}$ \\ ${ }^{1}$ Program Studi Sistem Informasi Universitas Raharja \\ ${ }^{2,3}$ Program Studi Teknik Informatika, Universitas Raharja \\ E-mail : ${ }^{1}$ desy@ raharja.info, ${ }^{2}$ dewi.immaniar@ raharja.info, \\ ${ }^{3}$ muhammad.zainalarifin@ raharja.info
}

\begin{abstract}
Abstrak
Pada penelitian ini akan dilakukan pembuatan perangkat untuk memantau posisi wireless access point menggunakan antena directional, processor ARM, Raspberry-Pi, data hasil pemantauan dari antena yang telah di proses oleh Raspberry-Pi akan ditampilkan pada GUI (Graphical User Interface) pada PC (Personal Computer). Bagian-bagian pada sistem ini adalah microprocessor Raspberry-Pi, motor servo, dan antena directional. Perangkat ini berfungsi untuk melakukan pencarian terhadap posisi sinyal terkuat atau posisi fisik dari sebuah access point. Directional antenna akan diputar $360^{\circ}$ oleh motor servo sehingga bisa mendapatkan data sinyal pada sudut-sudut yang dipantau. Data sinyal pada sudut-sudut tersebut akan dibandingkan sehingga akan didapatkan sudut/arah dari sinyal terkuat. Metode yang digunakan dalam penelitian ini, menggunakan metode diskusi, dilakukan dengan dosen dan mahasiswa Universitas Budi Luhur guna mendapatkan solusi mengenai permasalahan dan kekurangan dari sistem pemantau posisi wireless access point menggunakan antena directional yang dirancang. Sistem pemantau posisi arah access point ini bertujuan untuk mendapatkan hasil posisi atau posisi fisik access point yang akurat, yang berada di lingkungan kampus Universitas Budi Luhur.
\end{abstract}

Kata kunci : Antena Directional, Processor ARM, Raspberry-Pi, Posisi, Access Point, GUI.

\begin{abstract}
In this study will be conducted the manufacture of devices for wireless access point position monitoring using directional antennas, ARM processors, Raspberry-Pi, monitoring data from antennas that have been processed by Raspberry-Pi will be displayed in the GUI (Graphical User Interface) on a PC (Personal Computer). Parts of the system are the Raspberry-Pi microprocessor, servo motor, and directional antenna. This device serves to perform a search against the strongest signal position or physical position of an access point. The directional antenna will be rotated $360 \mathrm{o}$ by the servo motor so that it can get signal data at monitored angles. The signal data at these angles will be compared so that the angle/direction of the strongest signal will be obtained. The method used in this study, using the discussion method, was conducted with lecturers and students of Budi Luhur University to get solutions to the problems and shortcomings of the wireless access point position monitoring system using directional antennas designed. This access point directional position monitoring system aims to obtain accurate position results or physical position of access points, which are located within the campus of Budi Luhur University.
\end{abstract}

Keywords: Directional Antenna, ARM Processor, Raspberry-Pi, Position, Access Point, GUI

Vol.7 No.2 - Agustus 2021 


\section{PENDAHULUAN}

Perkembangan telekomunikasi saat ini semakin pesat, khususnya kebutuhan akan konektivitas dan akses data yang semakin meningkat sehingga mendorong pelaku bisnis telekomunikasi/operator telekomunikasi mengembangkan fasilitas mobile dan wireless broadband. Begitu juga dengan perangkat pendukungnya dibutuhkan perangkat yang dapat memadai, berkualitas dan efisien. Banyaknya jumlah lokasi pemasangan access point menjadikan penggunaan Wireless Access Control (WAC) adalah sebuah solusi untuk melakukan konfigurasi terpusat untuk access point. Sebuah Wireless Access Control (WAC) dapat mengatur sekitar 10.000 access point. Selain perangkat untuk melakukan konfigurasi secara terpusat, dibutuhkan perangkat lain untuk melakukan pemantauan terhadap konfigurasi yang telah dibuat pada WAC dan perangkat untuk melakukan estimasi posisi dari access point di lapangan.

Di Universitas Budi Luhur sendiri terdapat banyak access point yang memiliki perbedaan kuat sinyal dan di samping itu karena berbagai macam hambatan seperti gedung-gedung yang berada di area kampus sehingga dalam penyebaran sinyal untuk diterima oleh user tidak optimal, oleh karena itu penulis bermaksud membuat "Sistem Pemantau Posisi Wireless Access point Menggunakan Antena Directional". Sistem tersebut dibuat untuk dapat memantau serta menampilkan sudut letak-letak posisi wireless access point yang akurat yang berada di lingkungan kampus Universitas Budi Luhur, dengan memanfaatkan gelombang radio pada USB WiFi Adapter dan pemancar menggunakan antena directional yang tentunya akan dapat membantu untuk mengetahui posisi dan bentuk fisik access point dan user dapat menggunakannya di area dekat access point tersebut sehingga dapat mendapatkan pancaran sinyal yang optimal dari access point yang berada di lingkungan kampus Universitas Budi Luhur, karena antena directional adalah antena yang memiliki karakteristik dapat membaca sinyal dengan baik untuk menentukan arah sinyal terbaik dari access point.

\section{METODE PENELITIAN}

Untuk memperoleh data yang diperlukan dalam penelitian ini, metode penelitian yang digunakan yaitu metode perancangan untuk merancang hardware dan software sistem pemantau posisi wireless Access point menggunakan antena directional. Metode Pengujian, untuk menguji sistem pemantau posisi wireless access point menggunakan antena directional untuk mengetahui keakuratan antena dalam memantau dan mendapatkan letak hotspot access point di Lingkungan Kampus Universitas Budi Luhur. Metode diskusi, dilakukan dengan dosen dan mahasiswa Univeristas Budi Luhur guna mendapatkan solusi mengenai permasalahan dan kekurangan dari sistem pemantau posisi wireless access point menggunakan antena directional yang dirancang.

\section{LITERATURE REVIEW}

1. Penelitian yang dilakukan oleh Fransiska dan Danang Arbian Sulistyo, 2019. Dengan judul Analisis Penempatan Access Point Pada Jaringan Wireless LAN STMIK Asia Malang Menggunakan One Slope Model.penelitian ini menghasilkan walktest ini akan digunakan sebagai parameter untuk perhitungan teoritis menggunakan model propagasi One Slope Model (1SM). Hasil pengukuran menunjukkan bahwa semakin jauh jarak antara user dan AP, maka kuat sinyal yang diterima juga akan semakin kecil (dibuktikan dengan nilai kuat sinyal yang memiliki angka negatif semakin besar atau menjauhi angka positif). Dari penelitian ini dapat disimpulkan bahwa Hasil dari analisis di atas membuktikan bahwa keberadaan barrier mempengaruhi kekuatan sinyal yang diterima oleh user, sehingga penempatan perangkat WLAN, dalam hal ini AP perlu diperhatikan. 
2. Penelitian ini dilakukan oleh Ficky dan Febri Nurfalah, 2017 dengan judul "Analisis, Perancangan dan Implementasi Jaringan Wireless Point to Point Antar Kampus A dan Kampus B Universitas Negeri Jakarta. Yang dihasilkan dalam penelitian ini yaitu Jaringan wireless point to point berhasil diimplementasikan dengan hasil pengujian yaitu terdapat banyak interferensi dari wireless access point lain, sambungan berhasil dilakukan dengan $0 \%$ packet loss, kekuatan sinyal $-64,75 \mathrm{dBm}$, signal to noise 41,25 $\mathrm{dB}$, client connection quality $86,14 \%$, dan through put $11,15 \mathrm{Mbps}$.

3. Penelitian ini dilakukan oleh Rudi, dkk, 2020. Dengan judul buku "Analisis Celah Keamanan Jaringan Komputer dengan Menggunakan Raspberry Pi 3". Dalam buku ini menjelaskan tentang penggunaan Raspberry Pi 3 yang sangat dibutuhkan dalam keamanan jaringan, selain itu kelebihan dari Raspberry Pi 3 mempunyai port/koneksi untuk display berupa TV atau monitor PC serta koneksi USB. Dan dari buku ini penulis dapat mendapatkan pembelajaran tentang penggunaan Raspberry Pi 3 untuk keamanan dalam jaringan yang akan diteliti.

4. Penelitian yang dilakukan oleh Al, Januar dan Cuncun Wibowo, 2018 yang berjudul "Implementasi Wireless Mesh Network menggunakan Controller Access Point System Manager di Lingkungan Kampus Universitas Muhammadiyah Riau. Dari yang dihasilkan oleh penelitian ini penggunaan jaringan wireless mesh network dengan menggunakan teknologi control Akses Point Manager dan Control Akses Point memudahkan klien untuk berinternet secara mobile. Internet dapat diakses kapanpun dan dimanapun tanpa perlu auntentikasi kembali sehingga memudahkan administrator.

5. Penelitian ini dilakukan oleh Zefanya dan Billy Susanto Panca, 2019, yang berjudul "Deteksi Blind Spot pada Sinyal Akses Point menggunakan Metode Suite Survey. Hasil dari penelitian dan pengolahan data setelah melakukan pengukuran dan pengujian data adalah sebagai berikut: Jangkauan sinyal masih belum meliputi seluruh area dalam lab meskipun semua access point dalam kondisi menyala. Lab-lab berikut perlu diperhatikan karena rawan blind spot: Enterprise $1 \& 2$, Programming $1 \& 2$, Advance $1 \& 4$, Internet $1 \& 2$, Ruang Dosen dan Server, Meeting Room, Meeting Room S2, Ruang Staf 1, Ruang COMMIT.Persentase blind spot dari lab-lab yang rawan adalah sebagai berikut: (0-20\%) Advance 1, Advance 4,Internet 2.(20.01\%-25\%) Enterprise 2, Internet 1, Ruang Staf 1, Ruang COMMIT. (25.01\%-75\%) Programming 1, Programming 2, Ruang Dosen dan Server. (>75\%) Enterprise 1, Meeting Room S2, Meeting Room.Solusi dari masalah ini adalah dengan memindahkan access point dari lab yang tidak rawan ke lab yang rawan.Terdapat potensi masalah interferensi yang berasal dari sinyal access point diluar milik Fakultas Teknologi Informasi.

\section{HASIL DAN PEMBAHASAN}

Lokasi Pengujian Sistem ini dilakukan di Lingkungan Kampus Universitas Budi Luhur.Tujuan pengujian pada sistem keseluruhan ini adalah untuk mengetahui kerja sistem secara keseluruhan dalam mendeteksi sinyal dari wireless access point yang berada di lingkungan kampus Universitas Budi Luhur, lokasi pengujian adalah area indoor, yaitu di lantai 1 Unit 5, Pengujian dilakukan dengan scanning area yang telah ditentukan, Jarak lokasi scanning dari titik 1 ke yang titik. berikutnya dengan range jarak dari hasil putaran roda platform, Lokasi scanning seperti yang ditunjukan pada Gambar 1. 


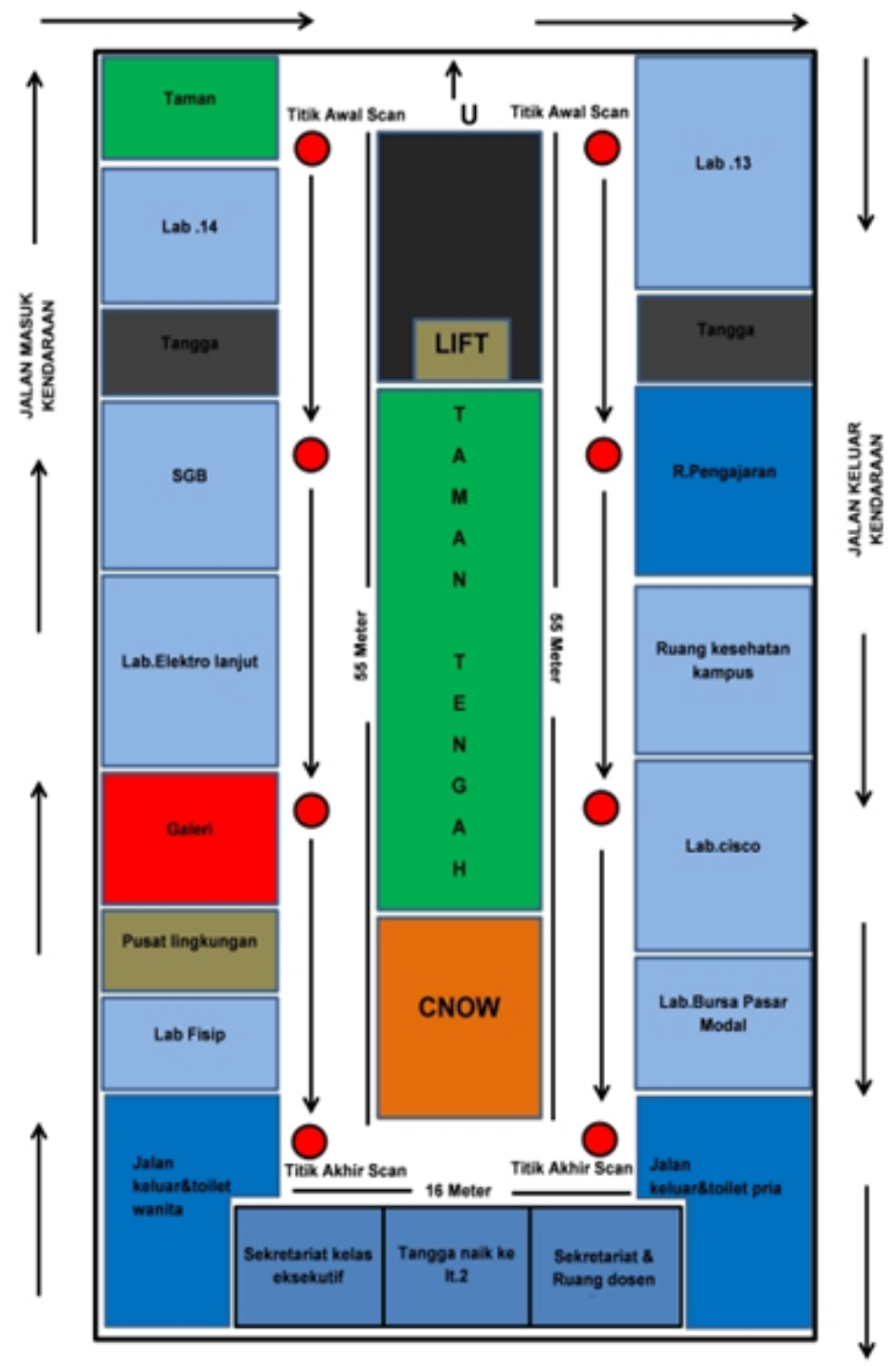

Gambar 1. Tampilan Lokasi Scanning Pengujian Sistem Pemantau Wireless Access Point

Hasil Scanning sistem pemantau posisi wireless access point mendapatkan sudut dan kuat sinyal di lokasi scanning titik 1 dan 2 dari wireless access point yang berada di lingkungan kampus Universitas Budi Luhur (Lantai 1 unit 5) dan hasil scanning hotspot wireless access point milik Universitas Budi Luhur, hasil lokasi scanning titik 1 dapat dilihat pada Tabel 1 dan hasil lokasi scanning titik 2 dapat dilihat pada Tabel 2, dan data hasil scanning dari kedua titik tersebut akan diambil sampel titik wireless access point untuk menentukan titik dan mendapatkan hasil lokasi berupa sudut dari letak fisik wireless access point. 
Tabel 1. Hasil Scanning Wireless Hotspot Access Point pada Titik 1

\begin{tabular}{|c|c|c|c|c|}
\hline No & Angle & RSSI & SSID & BSSID \\
\hline 1 & 30 degree & $-84 \mathrm{dBm}$ & Astri 01-Hospot & $00: 15: 6 D: 68: A 9: 2 E$ \\
\hline 2 & 70 degree & $-62 \mathrm{dBm}$ & UBL_Pengajaran & $00: 23: C D: 17: F 5: A 0$ \\
\hline 3 & 190 degree & $-79 \mathrm{dBm}$ & UBL_Excecutive & $68: 7 F: 74: A 9: 1 \mathrm{E}: 25$ \\
\hline 4 & 210 degree & $-85 \mathrm{dBm}$ & UBL_Hospot 3 & 0A:18:D6:CB:7B:76 \\
\hline 5 & 230 degree & $-79 \mathrm{dBm}$ & UBL_STUDENT & 0A:18:D6:9D:71:B5 \\
\hline 6 & 240 degree & $-50 \mathrm{dBm}$ & UBL_Hospot 1 & $00: 23: C D: 17: F 5: A 0$ \\
\hline 7 & 240 degree & $-87 \mathrm{dBm}$ & UBL_Hospot 6 & E8:DE:27:B7:D9:C2 \\
\hline 8 & 240 degree & $-73 \mathrm{dBm}$ & UBL_International & 0 AA:18:D6:91:36:E2 \\
\hline 9 & 260 degree & $-61 \mathrm{dBm}$ & UBL_PUSTAKA 1 & 2A:A4:3C:99:EF:78 \\
\hline 10 & 270 degree & $-80 \mathrm{dBm}$ & UBL_Auditorium & $68: 7 F: 74: A 9: 1 D: A 7$ \\
\hline 11 & 310 degree & $-77 \mathrm{dBm}$ & Astri 02-Hospot & $00: 24: 6 C: 5 B: 66: B 1$ \\
\hline 12 & 360 degree & $-67 \mathrm{dBm}$ & UBL_Pustaka 2 & 2A:A4:3C:99:F2:CD \\
\hline
\end{tabular}

Tabel 2. Hasil Scanning Wireless Hotspot Access Point pada Titik 2

\begin{tabular}{|c|c|c|c|c|}
\hline No & Angle & RSSI & SSID & BSSID \\
\hline 1 & 0 degree & $-86 \mathrm{dBm}$ & Astri 01-Hospot & 00:15:6D:68:A9:2E \\
\hline 2 & 20 degree & $-84 \mathrm{dBm}$ & Astri 02-Hospot & 00:24:6C:5B:66:B1 \\
\hline 3 & 50 degree & $-86 \mathrm{dBm}$ & UBL_REKTORAT & 2A:A4:3C:99:F2:FC \\
\hline 4 & 60 degree & $-89 \mathrm{dBm}$ & UBL_Hospot 3 & 0A:18:D6:CB:7B:76 \\
\hline 5 & 70 degree & $-72 \mathrm{dBm}$ & UBL_Pustaka 2 & 2A:A4:3C:99:F2:CD \\
\hline 6 & 130 degree & $-83 \mathrm{dBm}$ & LAB ICT Hospot 2 & 00:24:6C:5B:66:B1 \\
\hline 7 & 170 degree & $-59 \mathrm{dBm}$ & UBL_Hospot 1 & 00:23:CD:17:F5:A0 \\
\hline 8 & 190 degree & $-77 \mathrm{dBm}$ & UBL_Excecutive & 68:7F:74:A9:1E:25 \\
\hline 9 & 200 degree & $-68 \mathrm{dBm}$ & UBL_Theater & 00:15:6D:68:A9:2E \\
\hline 10 & 210 degree & $-90 \mathrm{dBm}$ & LAB ICT staff & 64:70:02:71:46:B8 \\
\hline 11 & 250 degree & $-64 \mathrm{dBm}$ & UBL_STUDENT & 0A:18:D6:9D:71:B5 \\
\hline 12 & 290 degree & $-65 \mathrm{dBm}$ & UBL_Pengajaran & 00:23:CD:17:F5:A0 \\
\hline 13 & 310 degree & $-83 \mathrm{dBm}$ & UBL_International & 0A:18:D6:91:36:E2 \\
\hline 14 & 340 degree & $-46 \mathrm{dBm}$ & UBL_PUSTAKA 1 & 2A:A4:3C:99:EF:78 \\
\hline
\end{tabular}


Tabel 3. Indikator Kuat Sinyal

\begin{tabular}{|c|c|c|}
\hline No & RSSI & BSSID \\
\hline 1 & $>-70 \mathrm{dBm}$ & Excellent \\
\hline 2 & $-70 \mathrm{dBm}$ to $-85 \mathrm{dBm}$ & Good \\
\hline 3 & $-86 \mathrm{dBm}$ to $-100 \mathrm{dBm}$ & Fair \\
\hline 4 & $<-100 \mathrm{dBm}$ & Poor \\
\hline 5 & $-110 \mathrm{dBm}$ & No Signal \\
\hline
\end{tabular}

Berdasarkan hasil lokasi scanning titik 1 pada Tabel 1 dan hasil lokasi scanning titik 2 pada Tabel 2, data hasil scanning dari kedua titik tersebut akan diambil 1 sampel wireless access point untuk mendapatkan hasil lokasi berupa sudut dari letak wireless access point, sampel tersebut dapat dilihat pada Tabel 4.

Tabel 4. Sampel Data dari Hasil Scanning Wireless Hotspot Access Point Pada Titik 1 dan 2

\begin{tabular}{|l|c|c|c|c|c|}
\hline No & $\begin{array}{c}\text { Lokasi Titik } \\
\text { Scanning } \\
\text { Access Point }\end{array}$ & Angle & RSSI & SSID & BSSID \\
\hline 1 & \multirow{2}{*}{$\mathbf{1}$} & 170 degree & $-59 \mathrm{dBm}$ & UBL_Hospot 1 & $00: 23: C D: 17: F 5: A 0$ \\
\cline { 3 - 6 } & \multirow{2}{*}{2} & 240 degree & $-46 \mathrm{dBm}$ & UBL_PUSTAKA 1 & 2A:A4:3C:99:EF:78 \\
\cline { 3 - 6 } & 2 & 260 degree & $-61 \mathrm{dBm}$ & UBL_PUSTAKA 1 & 2A:A4:3C:99:EF:78 \\
\hline
\end{tabular}

Penentuan Lokasi Access Point, dari tabel 4 maka didapatkan Gambar garis dengan Skala 1:100 seperti yang ditunjukan pada Tabel 4.

Menggunakan Antena Directional Pada sistem ini Raspberry-Pi yang digunakan adalah Raspberry-Pi tipe B. Microprocessor ini mendapat masukan tegangan sebesar 5 volt pada pin input power. Microprocessor Raspberry-Pi pada perangkat ini berfungsi sebagai pengendali utama sistem. Ukuran yang kecil dengan kemampuan interfacing dengan perangkat keras lain menjadikan dasar untuk menggunakan microprocessor ini sebagai unit pengendali utama dari sistem. 
Microprocessor ini memiliki 26 (dua puluh enam) buah pin GPIO(General Purpose Input Output) akan tetapi pada perancangan alat ini tidak semua dari port $I / O$ tersebut digunakan. Port I/O yang digunakan pada Microprocessor

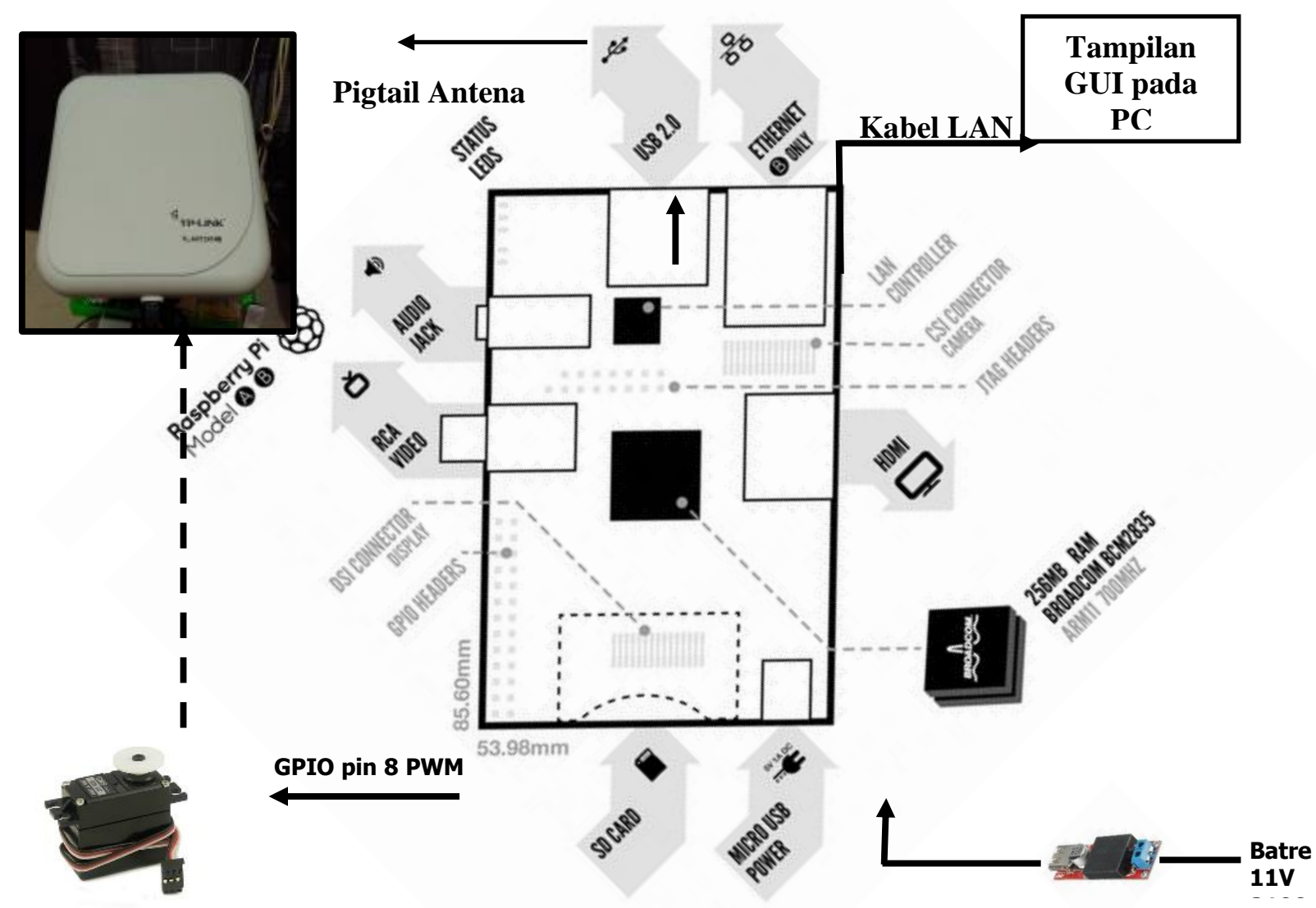

Kabel USB

Gambar 2. Rangkaian Microprocessor Raspberry-Pi Pada Sistem Pemantau Posisi WirelessAccess Point

Diagram Alir pada Raspberry-Pi, Pada diagram ini berisi tentang alur proses pengolahan hasil tangkapan sinyal dari antena Directional TP LINK TL-ANT2414B data tangkapan tersebut akan diproses oleh Raspberry-Pi lalu ditampilkan di HTML pada Laptop yang diterangkan pada Gambar 3. 


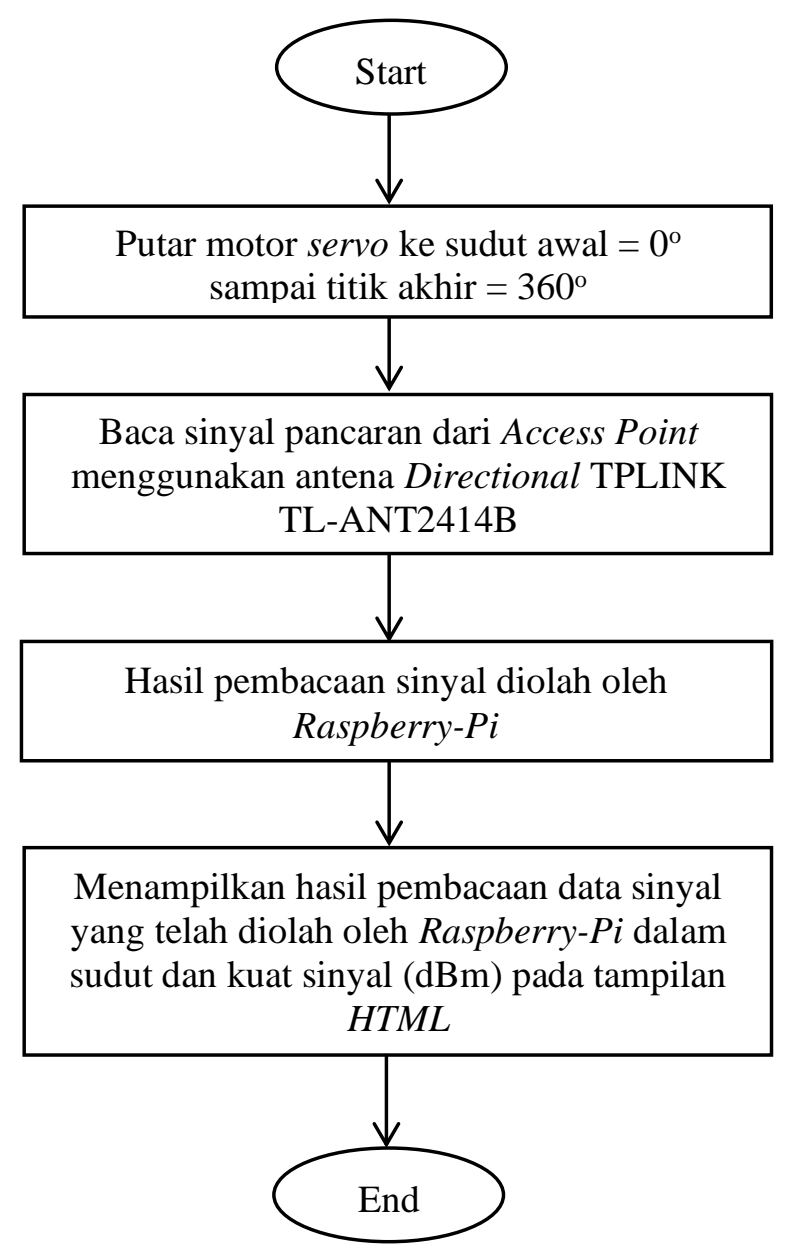

Gambar 3. Diagram Alir Pada Raspberry-Pi

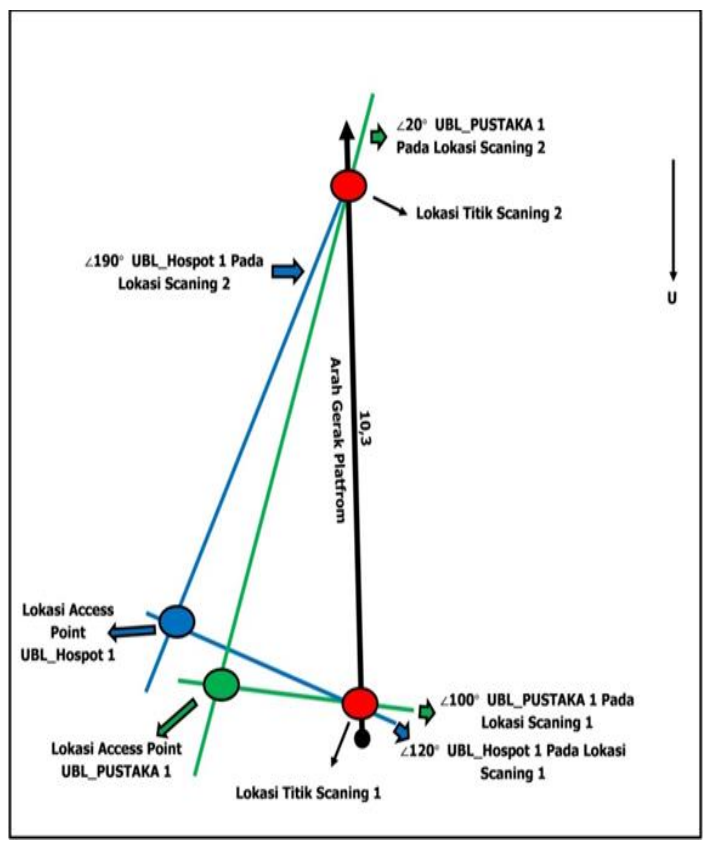

Gambar 4. Gambar Garis Potong Lokasi Access Point 
Berdasarkan hasil pada Gambar 4 potongan garis dari hasil scanning lokasi 1 dan 2 agar dapat menentukan lokasi berupa sudut dari letak fisik wireless access point, di Universitas Budi Luhur maka titik tersebut dimasukan kedalam Gambar Universitas Budi Luhur, pada Gambar 5.

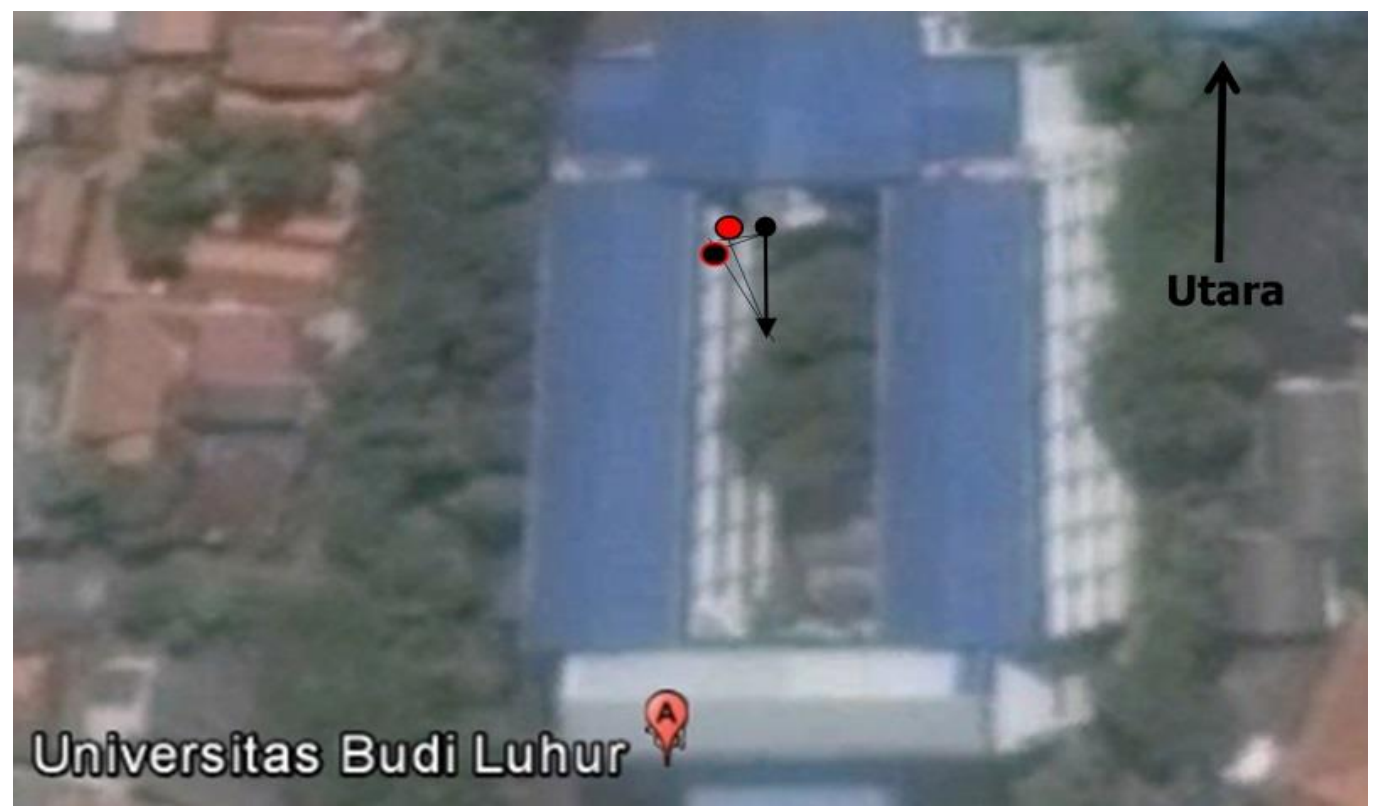

\section{Gambar 5. Gambar Penentuan Lokasi Access Point}

Keterangan gambar 5, Nomor 1 adalah Lokasi Scanning pada titik 1, Nomor 2 adalah Lokasi Scanning pada titik 2, titik bulat hitam pinggir merah merupakan lokasi access point Universitas Budi Luhur Hotspot 1 berdasarkan hasil perpotongan, titik bulat berwarna merah dengan pinggir bulatan warna hitam merupakan lokasi access point Universitas Budi Luhur Pustaka Satu berdasarkan hasil perpotongan.

Berdasarkan hasil pada Gambar 5 sistem dapat menentukan lokasi wireless access point yang berada di lingkungan kampus Universitas Budi Luhur posisi bentuk fisik wireless access point tepatnya berada di unit 6 lantai 3 seperti yang ditunjukan pada Gambar 6 dan gambar 7 .

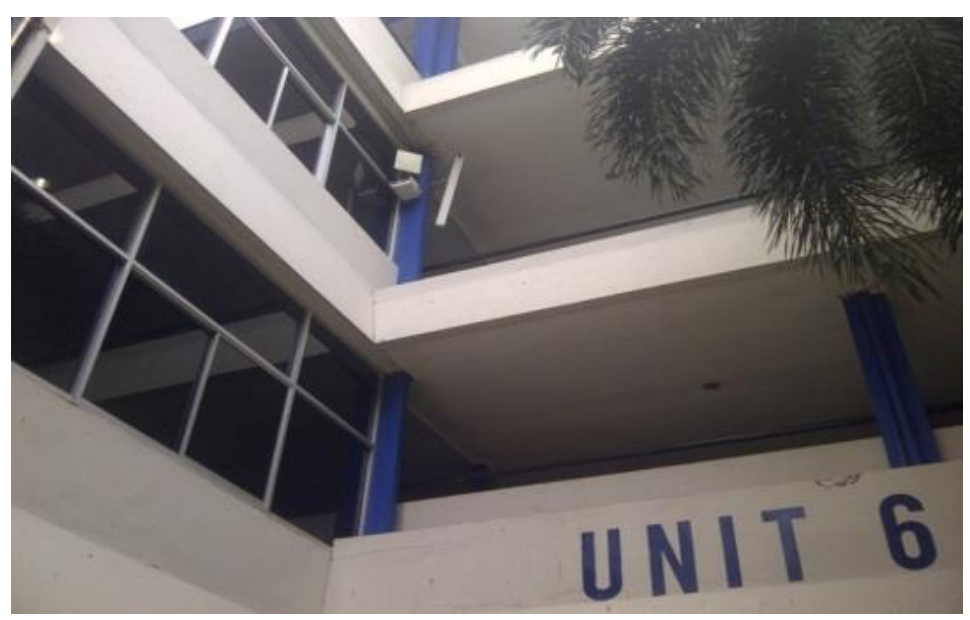

Gambar 6. Gambar Penentuan Lokasi Access Point 


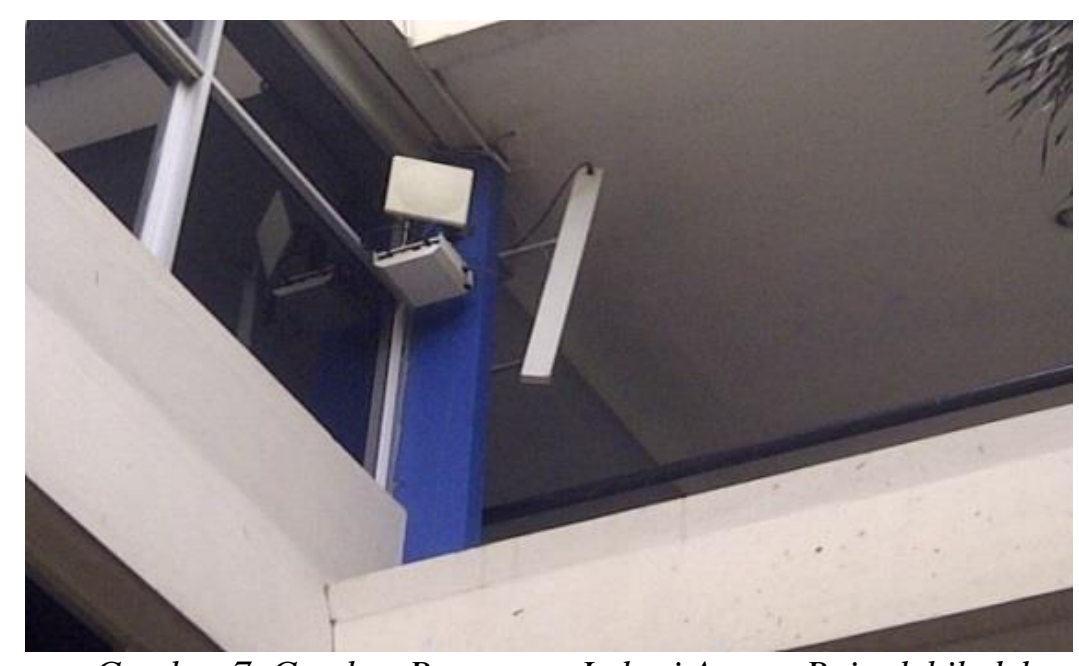

Gambar 7. Gambar Penentuan Lokasi Aceess Point lebih dekat

\section{KESIMPULAN}

Berdasarkan hasil pengujian yang telah dibahas pada bab sebelumnya, maka kesimpulan yang dapat diambil adalah sebagai berikut. Pengujian servoblaster dengan mengukur perubahan nilai tegangan pada pin GPIO ketika diberi sinyal $P W M$ menunjukkan adanya perubahan tegangan rata-rata sebesar $0.05 \mathrm{mV}$ untuk setiap perubahan pulsa T-ON sebesar 30 uS.Pengujian antena menunjukkan bahwa semakin jauh jarak dari wireless access point ke antena penerima, maka sinyal yang diterima akan semakin lemah yaitu $-21 \mathrm{dbm}$ pada jarak 1,8 Meter (WiFi 1$)$ dan $-41 \mathrm{dbm}$ pada jarak 3,4 Meter (WiFi 2) pada saat pengujian antena .Perangkat ini bekerja dengan baik untuk menentukan arah sinyal terbaik dari akses point. Arah sinyal tersebut adalah lokasi fisik dari sebuah wireless access point. Dari 2 titik lokasi scanning pengujian alat tersebut dapat memonitoring letak access point yang aktif yang berada di lingkungan kampus Universitas Budi Luhur

\section{DAFTAR PUSTAKA}

[1] Sisilia, Fransiska Mukti dan Danang Arbian Sulistyo, 2019. Analisis Penempatan Access Point Pada Jaringan Wireless LAN STMIK Asia Malang Menggunakan One Slope Model.Jurnal Ilmiah Teknologi Informasi Asia Volume. 13 No. 1. ISSN: 2580-8397.

[2] Ficky, M Duskarnaen dan Febri Nurfalah, 2017. Analisis, Perancangan dan Implementasi Jaringan Wireless Point to Point Antar Kampus A dan Kampus B Universitas Negeri Jakarta. Jurnal Pintar Vol. 1 No.2. ISSN: 2597-4475.

[3] Arief, Rudi Chandra, Nur, Dirja Ilham dan Arie Budiansyah, 2020, Analisis Celah Keamanan Jaringan Komputer dengan Menggunakan Raspberry Pi 3, CV Jejak, Bojong Genteng Jawa Barat.

[4] Al, Januar Amien dan Cuncun Wibowo, 2018, Implementasi Wireless Mesh Network menggunakan Controller Access Point System Manager di Lingkungan Kampus Universitas Muhammadiyah Riau, Jurnal Fasilkom, Vol.7, No. 2, ISSN: 2089-3353.

[5] Zefanya, Christian dan Billy Susanto Panca, 2019, Deteksi BlWSind Spot pada Sinyal Akses Point menggunakan Metode Suite Survey, Jurnal Strategi, Vol. 1, No. 1. 